\title{
Physiological effects of biocide on marine bivalve blue mussels in context prevent macrofouling
}

\author{
Md Niamul Haque ${ }^{1}$ and Sung-Hyun Kwon ${ }^{2 *}$
}

\begin{abstract}
Background: Mussels are stubborn organisms attached to solid substrata by means of byssus threads. The abundance of marine mussel Mytilus edulis in marine facilities like power stations was reason to select among fouling animals.

Methods: Mortality patterns as well as physiological behavior (oxygen consumption, foot activity, and byssus thread production) of two different size groups (14- and 25-mm shell length) of M. edulis were studied at different hydrogen peroxide concentrations $\left(1-4 \mathrm{mg} \mathrm{I}^{-1}\right)$.

Results: Studied mussels showed progressive reduction in physiological activities as the hydrogen peroxide concentration increased. Mussel mortality was tested in 30 days exposure, and $14 \mathrm{~mm}$ mussels reached the highest percentage of 90\% while $25 \mathrm{~mm}$ mussels reached 81\%. Produced data was echoed by Chick-Watson model extracted equation.

Conclusions: This study points that, while it could affect the mussel mortality moderately in its low concentrations, hydrogen peroxide has a strong influence on mussels' physiological activities related to colonization. Therefore, hydrogen peroxide can be an alternative for preventing mussel colonization on facilities of marine environment.
\end{abstract}

Keywords: Bivalve blue mussel, Biofouling, Hydrogen peroxide, Physiological behavior, Mortality

\section{Background}

Using seawater in cooling systems is a common practice in many parts of the world where there is a shortage of fresh water (Freese and Nozaic 2007), and that practice in coastal power plants is well-known (Mattice and Zittel 1976, Khalanski and Bordet 1980, Rajagopal. 1991). Fouling is the accumulation of unwanted material on solid surfaces to the detriment of function. The fouling nature is different according with the processes involved in its genesis. Usually, fouling is categorized into five types: biological (biofouling), corrosion, particulate, chemical reaction, and crystallization fouling (Epstein 1981). However, biofouling is one of the major operational problems associated with the usage of seawater in cooling systems, beside other problems like corrosion and scaling (Jenner et al. 1998). There are two broad categories of biofouling: macroscopic and microscopic. In

\footnotetext{
* Correspondence: shkwon@gnu.ac.kr

${ }^{2}$ Department of Marine Environmental Engineering, College of Marine Science, Engineering Research Institute (ERI), Gyeongsang National University, Cheondaegukchi-Gil 38, Tongyeong, Gyeongnam 650-160, South Korea
} Full list of author information is available at the end of the article macrofouling or macroinvertebrate fouling, clams, barnacles, and mussels block the seawater from properly flowing through the heat exchangers.

On the other hand, microbiologic fouling or microfouling is caused by the growth of slime and algae (Vaccaro et al. 1977). Controlling of macrofouling is the goal of this study. Consequently, mussels are bivalve molluscs belonging to the family Mytilidae. The common or blue mussel, Mytilus edulis, is among the most abundant and widely distributed invertebrate species inhabiting intertidal and shallow sub-tidal waters in the North Atlantic (Stewart 1994). It is also found in Arctic waters, Greenland, Atlantic coast, and Pacific coast, and as well as in European waters as far south as the Mediterranean and North Africa (Seed 1976). Sessile mussels such as M. edulis are often a major fouling species when their settlement and growth result in blockage of free flow of water in the conduits (Rajagopal 1991) and clogging of condenser tubes (Holmes 1970).

Though much work has been done in the area of the relative sensitivity (lethal and sub lethal) of the respective species to chlorine, there is lack of literature on 
hydrogen peroxide applications against marine mussel M. edulis. There are several published reports available on the response of other common tropical fouling mussels such as $P$. viridis, $P$. perna, $B$. striatulus, and $M$. philippinarum to chlorine (Rajagopal et al. 1997, 1995; Rajagopal et al. 2003a, b).

Since no information exists on the lethal and sub lethal effects of hydrogen peroxide on this mussel species, it is considered worthwhile to generate this data by exposing the mussels to a range of hydrogen peroxide concentrations. How does $M$. edulis respond physiologically under hydrogen peroxide conditions? Development of an antifouling strategy for Mytilus edulis would require that these questions be answered by way of careful experimentation. In the present study, we attempt to find answers in the laboratory using mussels collected from the site by subjecting different size groups of them to a range of hydrogen peroxide concentrations.

The objectives of this study, therefore, were to (1) understand the physiological response of $M$. edulis to hydrogen peroxide environments and (2) study lethality in 30 day's duration. It is presumed that hydrogen peroxide environment might be effective against settling and growing of blue mussels in cooling water system, although this biocide was a little successful in the case of zebra mussels.

\section{Methods}

\section{Mussel assortment and preservation}

Mussels for the experiments were collected from Jinhae-gu, Changwon-si, South Korea ( $35^{\circ} 07^{\prime} 39.5^{\prime \prime} \mathrm{N}$ and $128^{\circ} 44^{\prime}$ $19.8^{\prime \prime}$ E). Mussels were grown for commercial purpose. The experimental mussels were collected as attached with growing rope, and mussels attached with ropes were preserved in continuous seawater flowing glass aquarium. The mussels were gently removed from the rope by cutting their byssus threads using a pair of scissors and immediately transferred to an ice box. The ice box had conveyed in laboratory within minimum time and minimum hassle. Seawater collected from the Gyeongsangnam-do Fisheries Resources Institute, South Korea, was used for accustoming M. edulis under standard laboratory conditions. Mussels acclimated for at least $48 \mathrm{~h}$ in the laboratory were used for each experiment.

\section{Peroxide sample preparation and laboratory study method}

Seawater collected from Gyeongsangnam-do Fisheries Resources Research Institute, South Korea, was used for the experiment, after a day's storage. Factors that may change the response of the mussels such as salinity (mean $\pm \mathrm{SD} ; 33.47 \pm 0.2 \%$ o salinity, $20.0 \pm 0.4{ }^{\circ} \mathrm{C}$ temperature, 6.2 $\pm 0.5 \mathrm{mg} \mathrm{l}^{-1}$ dissolved oxygen, and $7.8 \pm 0.1 \mathrm{pH}$ ) did not show any considerable variation during the course of the experiments. The experiments were conducted in continuous static peroxide system, following the slight adjusted procedure outlined by Rajagopal et al. (1997). Seawater was stored in a 150-l aquarium tank, and peroxide stock solution (1000 $\mathrm{mg} \mathrm{l}^{-1}$ ) prepared from $30 \%$ solution (MERK, Germany), was stored in a 1-l volumetric flask. Using a micropipette, an appropriate mix of the two was employed to maintain the desired peroxide concentration in a 2-l glass beaker, with the outside at the 2-1 mark. Mixing of the water was speed up by the glass stirrer. After 2 days of acclimation, 20 for $14 \mathrm{~mm}$, and 20 for $25 \mathrm{~mm}$ size randomly picked mussels were introduced into the experimental glass beaker containing seawater of known peroxide $\left(1.0,2.0,3.0\right.$, and $\left.4.0 \mathrm{mg} \mathrm{l}^{-1}\right)$ concentrations. Hydrogen peroxide concentration was determined by thiosulfate titration, using a Hach hydrogen peroxide test kit, model HYP-1. The levels of the total residual $\mathrm{H}_{2} \mathrm{O}_{2}$ were monitored at 30 -min intervals.

\section{Sub lethal responses}

Oxygen consumption, foot activity index, and byssus thread production of two size groups of Mytilus edulis were also studied at five different peroxide concentrations (0, 1, 2, 3, and $4 \mathrm{mg} / \mathrm{L}$ ). Experiment were run as detailed as below.

\section{Oxygen consumption}

The oxygen consumption was determined via the method of Bruijs et al. (2001). A closed glass respiratory chamber $(750 \mathrm{ml})$, placed inside a double-walled glass beaker (to minimize temperature changes), was filled with Millipore $(0.45 \mu \mathrm{m})$ filtered seawater $(500 \mathrm{ml})$ previously aerated to $100 \%$ oxygen saturation. Five mussel of a particular size group were placed together in the chamber for each measurement. In each experiment, 8 replicate measurements were taken (5 mussels in each experiment $\times 5$ peroxide doses including control $\times 2$ size groups $\times 8$ replicates $=400$ mussels $)$. Control measurements were performed using the same setup but without mussels. The oxygen content of the water was determined at the start and end of each run ( $1 \mathrm{~h})$ by Winkler method (Strickland and Parsons 1972). The amounts of oxygen used by the animals were taken as the average differences in oxygen concentration between the measurements with animals and the controls. Oxygen consumption was expressed in $\mathrm{ml} \mathrm{O}_{2} /$ mussels/h. The rate of oxygen consumption (ROC) was calculated as

$$
\text { ROC }=\frac{\text { oxygen in control }(\mathrm{ml} / \mathrm{l})-\text { oxygen in experimental set }(\mathrm{ml} / \mathrm{l})}{\text { duration }(\mathrm{h})} .
$$

\section{Foot activity indexing}

For foot activity index, six mussels were kept in 21 of seawater and left undisturbed for $24 \mathrm{~h}$. Every $10 \mathrm{~min}$, 
the number of mussels with foot extended outside their shell was noted (Holmes 1970). No attempt was made to follow the foot activity of individual mussels. For each experiment, the foot activity of all mussels was analyzed and was expressed as times/mussels/hour (5 mussels per experiment $\times 5$ peroxide concentrations (including control) $\times 2$ size groups $\times 8$ replicate $)=400$ mussels .

\section{Byssus thread production}

Byssus thread production was determined following procedures outlined by Van Winkle (1970) and Rajagopal et al. (1995). After $48 \mathrm{~h}$ of acclimation, one mussel was placed in a 11 glass beaker containing $0.75 \mathrm{~L}$ of seawater of known peroxide concentration ( 1 mussel per experiment $\times 5$ peroxide concentrations (including control) $\times 2$ size groups $\times 8$ replicate) $=80$ mussels). By using only one mussel per container, there was no need to code the mussels, and any problems of counting threads (when mussels clump, which they invariably did) were prevented (Rajagopal et al. 1997). The byssus threads produced by mussels were counted after $24 \mathrm{~h}$ and expressed as threads mussel ${ }^{-1}$ day $^{-1}$ (Van Winkle 1970).

\section{Mortality experiment}

Two size groups of Mytilus edulis (shell length in $\mathrm{mm} \pm$ SD; $14.0 \pm 0.24$. and $25.2 \pm 0.34$ ) were tested at six different peroxide concentrations including control (control, 1.0, 2.0, 3.0, 4.0, and $5 \mathrm{mg} \mathrm{L}^{-1}$ ).

In the earliest experiments, comparable mortality responses were observed between fed (mixed algal culture) and non-fed Brachidontes varoabilis, when exposed to chlorination. Similar observations were also reported earlier for P. viridis (Rajagopal et al. 1995), B. striatulus (Rajagopal et al. 1997), and P. perna (Rajagopal et al. 2003a, b). Therefore, Mytilus edulis used in the present study were not fed during the course of the experiment. Mortality was assessed at 6-h intervals. The criterion for mortality of mussels was a shell valve gape with no response of exposed mantle tissue to external stimuli (Rajagopal et al. 1997). Dead mussels were immediately removed from the flask. The number of dead animals in each experiment was recorded, along with their shell lengths and total weights for each observation event. The same experiment was repeated three times for each size group and peroxide concentration (14 and $25 \mathrm{~mm}$ (20 mussels in each experiment $\times 5$ peroxide concentration (including control) $\times 2$ size groups $\times 3$ replicates $=$ 720 mussels)).

\section{Kinetic model (disinfection) for mussel mortality}

An important feature of kinetic modeling is not only to simplify but also to idealize a complex phenomenon of cleansing systems. With the data from these experiments designated above, we attempted to determine the coefficients of selected models. The major principles of disinfection kinetics were articulated by Chick and recognized the close similarity between microbial inactivation by chemical disinfectants and chemical reactions (Chick, 1908). From Chick's law, if $N_{0}$ is the number of organisms when $t$ equal 0 , it can be expressed as

$$
\log \left(N / N_{0}\right)=-k * t
$$

where

$N=$ a number of microorganism at contact time $t$

$N_{0}=$ a number of initial microorganism at contact time, $t=0$

$k^{*}=$ inactivation rate constant

$t=$ contact time

Watson (1908) proposed an empirical logarithmic function to relate the rate constant of inactivation, " $k^{*}$ " to the disinfectant concentration " $C$ " (). In general, disinfection systems are designed by the "Ct" values derived from Chick-Watson kinetics based on the data obtained from laboratory inactivation studies.

$$
\begin{aligned}
& k *=k C^{n} \\
& \log \left(N / N_{0}\right)=-k C^{n} t,
\end{aligned}
$$

where

$k=$ constant for a specific microorganism and set of conditions

$C=$ disinfectant concentration

$n=$ coefficient of dilution

The Watson function, Eq. (4), is based on the assumption that microorganisms are genetically similar and of a single strain of synchronous development and the killing action would be a single-hit and single-site type. The assumptions are necessary in order to derive the ChickWatson model based on a chemical reaction mechanism. In many cases, the $n$ value for Chick-Watson law is close to 1.0, and hence, a fixed value of the product of concentration and time (Ct product) results in a fixed degree of inactivation (AWWA 1999).

\section{Results}

Sub lethal responses

\section{Oxygen consumption}

In control experiments, mussel in the 25 and $14 \mathrm{~mm}$ size group showed a maximum oxygen consumption rate of $3.13 \mathrm{ml} \mathrm{O}_{2}$ mussel $^{-1} \mathrm{~h}^{-1}$. In control, the oxygen consumption did not show potential difference with respect to the size of mussels. Oxygen consumption of blue mussel species at different peroxide levels showed a progressive decline as the peroxide increased from 1.0 to $4.0 \mathrm{mg} \mathrm{l}^{-1}$ (Fig. 1). For example, oxygen consumption of $14 \mathrm{~mm}$ mussel showed a 

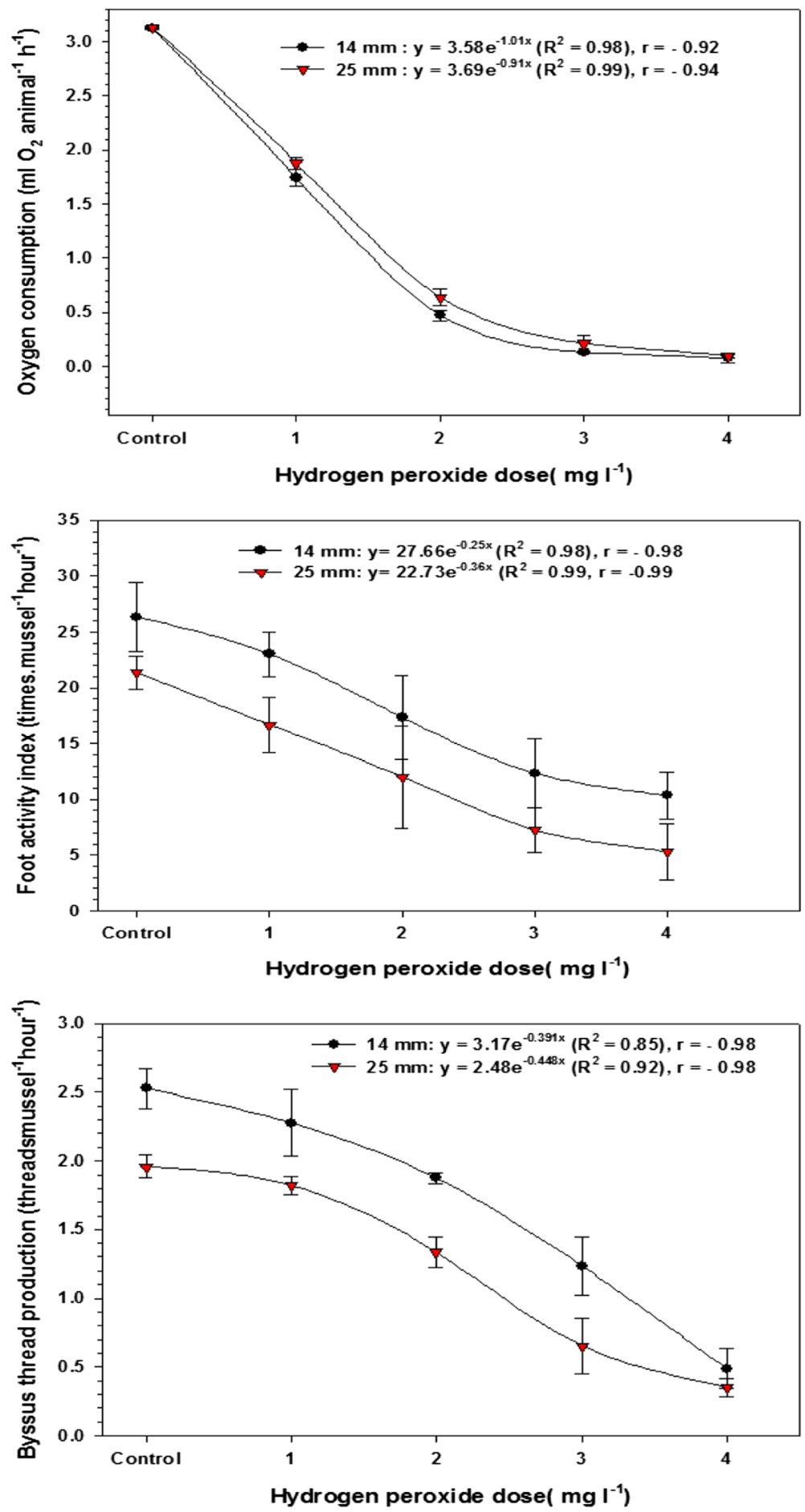

Fig 1 Relationship between $\mathrm{H}_{2} \mathrm{O}_{2}$ concentration and physiological activities of Mytilus edulis

reduction of $98 \%$ with $4 \mathrm{mg} \mathrm{l}^{-1}$ peroxide concentration and $44 \%$ with $1 \mathrm{mg} \mathrm{l}^{-1}$ peroxide concentration compare with control. Data also show a clear size dependent variation in oxygen consumption. As the size increased, progressive increase in oxygen consumption was observed.
Foot activity index

The highest foot activity index decrease was measured $60 \%$ in $4 \mathrm{mg} \mathrm{l}^{-1}$ peroxide experiments with $14 \mathrm{~mm}$ mussel (Fig. 1) and 75\% with $25 \mathrm{~mm}$ mussel when compared with control. As peroxide concentration decreased, the foot activity index also decreased 
accordingly. For example, foot activity index of $14 \mathrm{~mm}$ mussel was decrease $12 \%$ at $1 \mathrm{mg} \mathrm{l}^{-1}$ peroxide when it was $53 \%$ at $3 \mathrm{mg} \mathrm{l}^{-1}$. Foot activity index decreasing with peroxide concentration for 14 and $25 \mathrm{~mm}$ mussel was shown in Fig. 1.

\section{Byssus thread production}

The byssus thread production of M. edulis showed a progressive decline as the peroxide concentration inceased. The smaller mussels showed higher byssus production. For example, $14 \mathrm{~mm}$ size mussel showed $2 \%$ higher byssus thread production than $25 \mathrm{~mm}$ at $4 \mathrm{mg} \mathrm{l}^{-1}$ peroxide (Fig. 1). However, byssus thread production of subjected to continuous peroxide application showed a reduction of 10 to $80 \%$ of $14 \mathrm{~mm}$ and $7 \%$ to $82 \%$ of 25 mussels group when compared to control experiments.

\section{Mortality}

Two size group $M$. edulis mussels were tested at the standard laboratory condition. The time required for $100 \%$ mortality of Mytilus edulis mussel exposed to different hydrogen peroxide levels was measured. With 30 days exposure to peroxide, the lethal percentage has not reached $100 \%$ mortality. However, the cumulative mean mortality of mussel within studied period was represented by Fig. 2. No mortality observed in control tanks. Smaller size mussels were dead at higher percentage than the bigger size ones. For example, $14 \mathrm{~mm}$ mussels showed $90 \%$ mortality whereas $25 \mathrm{~mm}$ mussels
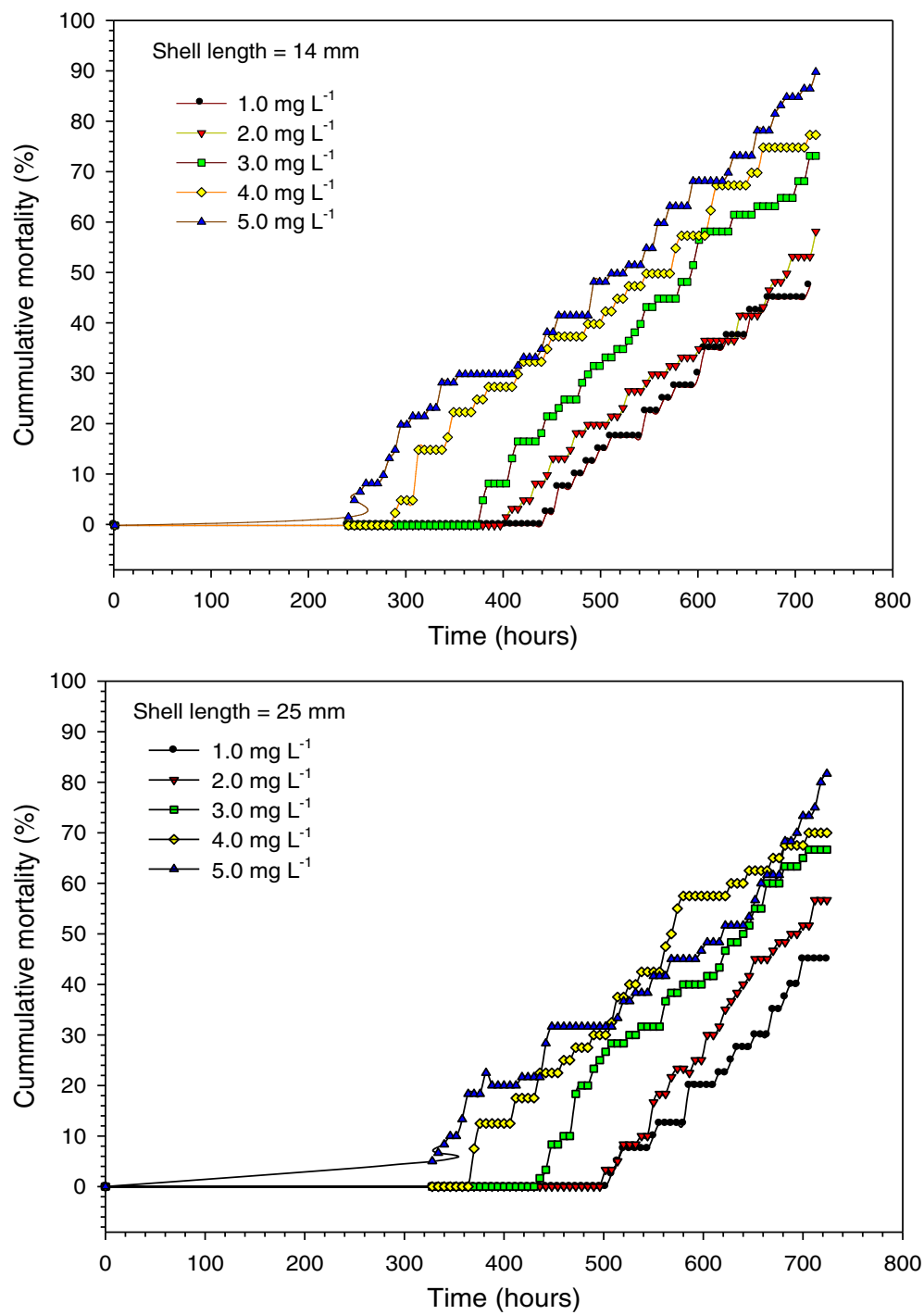

Fig. 2 Time course variation of mussel mortality [14 mm (top) and $25 \mathrm{~mm}$ (bottom)] of blue mussels at five different hydrogen peroxide concentrations $\left(1-5 \mathrm{mg} \mathrm{l}^{-1}\right)$ 


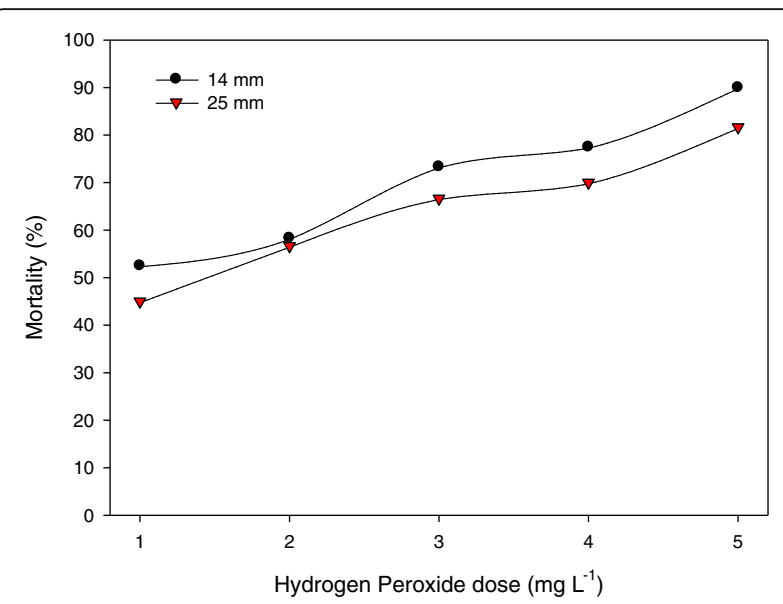

Fig. 3 Comparison of mortal percentage of Mytilus edulis at different concentrations of peroxide in 30 days exposure

reached $81 \%$ mortality in $5 \mathrm{mg} \mathrm{l}^{-1}$ peroxide concentration (Fig. 3).

\section{Kinetic-based analysis of mortality}

Based on the Chick-Watson model, the inactivation degrees on $\mathrm{Ct}$ value were presented in Fig. 4. As seen in Eq. (4), the estimated $k$ values were found to be " 0.0005 " and "0.0004" for 14 and $25 \mathrm{~mm}$ size mussels, respectively.

$$
\begin{aligned}
& \log \left(N / N_{0}\right)=-0.0005 C t \\
& \log \left(N / N_{0}\right)=-0.0004 C t
\end{aligned}
$$

The $\log$ inactivation value was greater for $14 \mathrm{~mm}$ size mussel than $25 \mathrm{~mm}$ mussel. At the same, $C t$ value for $5 \mathrm{mg} \mathrm{l}^{-1}$, the maximum $\log$ inactivation values were $2-\log$ and $1.5-\log$ for $14-$ and $25-\mathrm{mm}$ size mussels, respectively (Table 1).

\section{Discussion}

In the present study, peroxide concentration as low as $1 \mathrm{mg} \mathrm{l}^{-1}$ to higher $4 \mathrm{mg} \mathrm{l}^{-1}$ was used to assess the physiological processes of mussel. Even at the lower level, peroxide tends to interfere with the physiological processes at $1 \mathrm{mg} \mathrm{l}^{-1}$ peroxide, for instance. The experiments conducted in the present study were aimed to ascertain the effects of peroxide administered at low levels on the physiological processes such as oxygen consumption, foot activity, and byssus thread production of test mussels. It may be noted that all these three activities are directly correlated to valve opening of mussels. The data in general show decreased activity with increasing peroxide concentrations. Valve opening was affected even at the lowest concentration $\left(1.0 \mathrm{mg} \mathrm{l}^{-1}\right)$, indicating that the entire mussel could sense the presence of chlorine at such low levels. By monitoring valve opening in M. edulis species, a 14-mm mussel was known to open its valve more frequently than any $25 \mathrm{~mm}$ size mussels.

Laboratory tests of the biocide using model organisms are necessary to find its optimal concentrations for adequate fouling control at different sites (Claudi and Mackie 1994, Rajagopal et al. 2002). The most obvious feature of bivalve is the protective shell. During peroxide application, mussels shut their valves (Khalanski and Bordet 1980) and halt byssus thread production (Rajagopal et al. 1997). By doing it, bivalves isolate their body tissues from any changes caused by the external environment. At a high toxic external

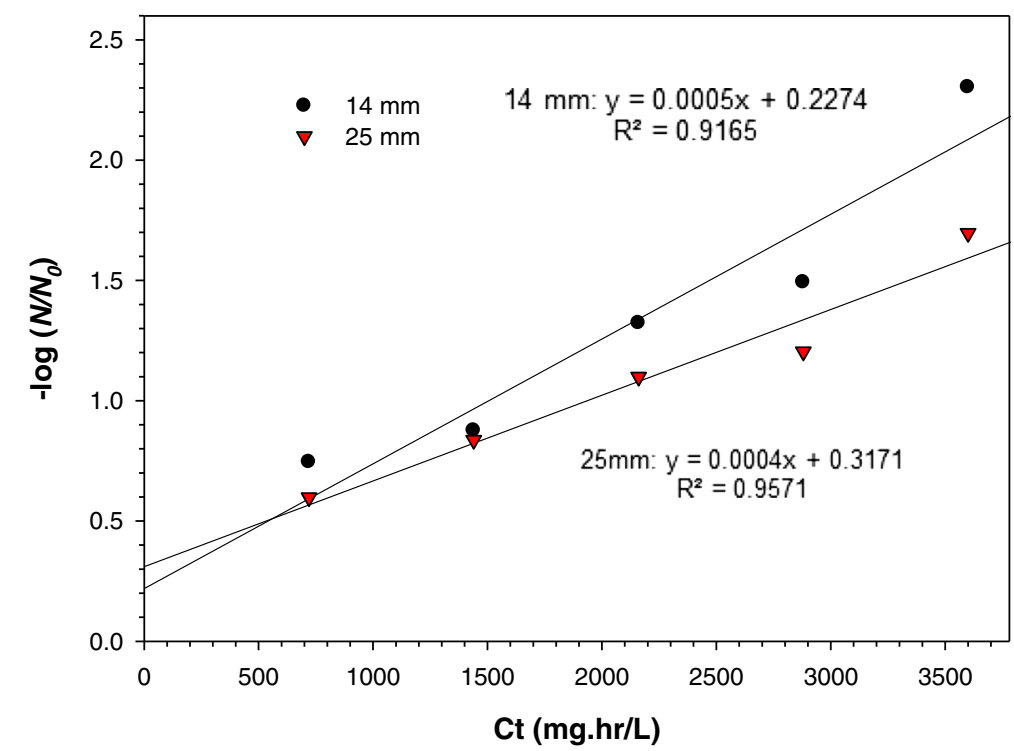

Fig. 4 Time course variation of mortality of blue mussels at five different hydrogen peroxide concentrations $\left(1-5 \mathrm{mg}^{-1}\right)$ 
Table 1 Estimated $C t$, log inactivation value, and rate constant of inactivation for death of Mytilus edulis with residual hydrogen peroxide

\begin{tabular}{|c|c|c|c|c|c|}
\hline \multirow{2}{*}{$\begin{array}{l}\mathrm{H}_{2} \mathrm{O}_{2}\left(\mathrm{mg} \mathrm{l}^{-1}\right) \\
\mathrm{C} \\
\end{array}$} & \multirow{2}{*}{$\begin{array}{l}{[\mathrm{Ct}]\left(\mathrm{mg} \mathrm{h} \mathrm{l}^{-1}\right)} \\
t=30 \text { day }(720 \mathrm{~h})\end{array}$} & \multicolumn{2}{|c|}{$\begin{array}{l}\text { Log inactivation } \\
{\left[-\log \left(N / N_{0}\right)\right]}\end{array}$} & \multicolumn{2}{|c|}{$\begin{array}{l}\text { Rate constant of } \\
\text { inactivation, }[\mathrm{K}]\end{array}$} \\
\hline & & 14 mm & $25 \mathrm{~mm}$ & $14 \mathrm{~mm}$ & $25 \mathrm{~mm}$ \\
\hline 1.0 & 720 & 0.74444 & 0.59784 & 0.0005 & 0.0004 \\
\hline 2.0 & 1440 & 0.87547 & 0.83625 & & \\
\hline 3.0 & 2160 & 1.32176 & 1.09861 & & \\
\hline 4.0 & 2880 & 1.49165 & 1.20397 & & \\
\hline 5.0 & 3600 & 2.30259 & 1.69645 & & \\
\hline
\end{tabular}

environment, mussels are forced to shut their valves and rest in stored food reserves and anaerobic respiration until energy resources are depleted or metabolic wastes reach toxic levels. The lag period of Fig. 2 might portray those reserved energy resources of test mussels. However, influence of other factors such as sex (Martin et al. 1993a), season (Jenner 1985), and reproductive differences (Martin et al. 1993b) - that may cause greater biocide resistance-cannot be discounted.

$\mathrm{H}_{2} \mathrm{O}_{2}$ can not only act as an oxidizing agent on the skin of living organism but also produce hydroxyl radicals, which are known to be harmful to living cells. Especially, the radical formation could be accelerated in the presence of metallic ions like in seawater mood. In that context, we assume that hydroxyl radicals along with oxidizing factor of $\mathrm{H}_{2} \mathrm{O}_{2}$ may terminate lives of blue mussels through a complicated, internal breakdown mechanism. The Chick-Watson model with $n=1$ reflected fairly the data shown in Fig. 4.

\section{Conclusions}

From the present study, it is clear that marine bivalve Mytilus edulis is sensitive even to lower peroxide environment. Physiological behavior (oxygen consumption, foot activity, and byssus thread production) showed decreasing pattern unanimously with increasing peroxide concentrations. Young mussel showed higher physiological activity than older mussel. The higher activity seems to be more vulnerable or susceptible to any external disturbances like hydrogen peroxide, though. Therefore, early stage in mussel cultivation is always better in order to prevent its colonization, followed by macrofouling. As a result, hydrogen peroxide is found to be a prospective biocide for preventing mussel colonization on marine environment.

\section{Acknowledgements}

This research was a part of the project entitled as "Improvement Technologies of Hypoxic Water Mass in Semi-Enclosed Coastal Bay," funded by the Ministry of Oceans and Fisheries, and BK21 plus program, South Korea.
Authors' contributions

Both authors read and approved the final manuscript.

\section{Competing interests}

The authors declare that they have no competing interest.

\section{Author details}

'Department of Ocean System Engineering, College of Marine Science, Gyeongsang National University, Cheondaegukchi-Gil 38, Tongyeong, Gyeongnam 650-160, South Korea. ²Department of Marine Environmental Engineering, College of Marine Science, Engineering Research Institute (ERI), Gyeongsang National University, Cheondaegukchi-Gil 38, Tongyeong, Gyeongnam 650-160, South Korea.

Received: 14 March 2016 Accepted: 31 August 2016

Published online: 24 December 2016

\section{References}

AWWA. (1999). Water quality and treatment (5th ed., pp. 22-32). New York: McGraw-Hill.

Bruijs, M. C. M., Kelleher, B., van der Velde, G., \& bij de Vaate, A. (2001). Oxygen consumption, temperature and salinity tolerance of the invasive amphipod Dike rogammarus villosus: indicators of further dispersal via Ballast water transport. Archiv für Hydrobiologie, 152, 633-646.

Chick, H. (1908). An investigation into the laws of disinfection. Journal of Hygiene (Cambridge), 8, 92-158.

Claudi, R., \& Mackie, G. L. (1994). Practical manual for zebra mussel monitoring and control. London: Lewis Publishers.

Epstein, N. (1981). Thinking about heat transfer fouling: a $5 \times 5$ matrix. Heat Transf. Eng, 4, 43-56.

Freese, S. D., \& Nozaic, D. J. (2007). Chlorine based disinfectants: how do they compare? Water Science and Technology, 55(10), 403-411.

Holmes, NJ, (1970). The effects of chlorination on mussels. Report No. RD/ L/R 1672, Central Electricity Research Laboratories, Leatherhead, Surrey, pp. $1-20$.

Jenner, HA (1985). Chlorine minimization in macrofouling control in the Netherlans. In: Jolly RL, Bull RJ, Davies WP, Katz S, Roberts MH, Jacobs VA(Eds.), Water chlorination: Chemistry, Environmental Impact and Health Effects. Vol 5 Lewis publishers, London, pp.1425-1433.

Jenner, HA, Whitehouse, JW, Taylor, CJL and Khalanski, M (1998). Cooling water management in European power stations: biology and control, pp.1-225. Hydroe'cologieAppliquee 1-2, Chatou, Paris: Electricite' de France.

Khalanski, M, Bordet, F (1980). Effects of chlorination on marine mussels. In: Jolly RL, Brungs WA, Cumming RB(Eds.), Water Chlorination: Chemistry, Environmental Impact and Health Effects, vol. 3. Ann Arbor, Michigan, pp. 5577567

Martin, ID, Mackie, GL, Baker, MA, (1993a). Control of the biofouling mollusc, Dreissena polymorpha (Bivalvia: Dreissenidae), with sodium hypochlorite and with polyquaternary ammonia and benzothiazole compounds. Archives of Environmental Contamination and Toxicology, 24, 381-388.

Martin, ID, Mackie, GL, Baker, MA. (1993b). Acute toxicity tests and pulsed-dose delayed mortality at 12 and $22^{\circ} \mathrm{C}$ in the zebra mussel (Dreissena polymorpha). Archives of Environmental Contamination and Toxicology, 24, 389-398.

Mattice, J. S., \& Zittel, H. E. (1976). Site-specific evaluation of power plant chlorination. Journal of the Water Pollution Control Federation, 48, 2284-2308.

Rajagopal, S (1991). Biofouling problems in the condenser cooling circuit of a coastal power station with special reference to green mussel, Pernavividis (L.). Ph. D. thesis. University of Madras, India, pp. I-113.

Rajagopal, S., Venugopalan, V. P. Nair, K. V. K. \& Azariah, J. (1995). Response of green mussel, Perna viridis (L.) to chlorine in the context of power plant biofouling control. Marine and Freshwater Behaviour and Physiology, $25,261-274$

Rajagopal, S., Nair, K. V. K., Van der Velde, G., \& Jenner, H. A. (1997). Response of mussel, Brachidontes striatulus, to chlorination: an experimental study. Aquatic Toxicology, 39, 135-149.

Rajagopal, S., Van der Velde, G., \& Jenner, H. A. (2002). Does status of attachment influence chlorine toxicity in zebra mussel, Dreissena polymorpha. Environmental Toxicology and Chemistry, 21, 342-346.

Rajagopal, S, Venugopalan, VP, Van der Velde, G, Jenner, HA. (2003a). Tolerance of five species of tropical marine mussels to continuous chlorination. Marine Environment Research, 55, 277-291. 
Rajagopal, S, Venugopalan, VP, Van der Velde, G, Jenner, HA. (2003b). Response of fouling brown mussel, Pernaperna (L.), to chlorine. Archives of Environmental Contamination and Toxicology, 44, 269-276

Seed, R. (1976). Ecology. In B. L. Bayne (Ed.), Marine mussels: their ecology and physiology (pp. 13-66). Cambridge, UK: Cambridge University Press.

Stewart, P. L. (1994). Environmental requirements of the blue mussel (Mytilus edulis) in eastern Canada and its response to human impacts. Canadian Technical Report of Fisheries and Aquatic Sciences, 2004. 41

Strickland, T. D. H., \& Parsons, T. R. (1972). A practical hand book of seawater analysis. Ottawa: Fisheries Research Board of Canada.

Vaccaro, R. F., Azam, F., \& Hadson, R. E. (1977). Response of natural marine bacterial populations to copper: controlled ecosystem population experiment. Bulletine of Marine Science, 27(1), 17-22.

Van Winkle, W. V. (1970). Effects of Environmental Factors on Byssal Thread Formation. Marine Biology, 7, 143-148.

Watson, H. E. (1908). A note on the variation of the rate of disinfection with change in the concentration of the disinfectant. Journal of Hygiene (Cambridge), 8, 536-542.

Submit your next manuscript to BioMed Central and we will help you at every step:

- We accept pre-submission inquiries

- Our selector tool helps you to find the most relevant journal

- We provide round the clock customer support

- Convenient online submission

- Thorough peer review

- Inclusion in PubMed and all major indexing services

- Maximum visibility for your research

Submit your manuscript at www.biomedcentral.com/submit
) Biomed Central 